\title{
HUBUNGAN RASIO KOLESTEROL TOTAL-HDL DAN RASIO LINGKAR PINGGANG-PANGGUL DENGAN STROKE DI RSUD RADEN MATTAHER JAMBI TAHUN 2016
}

\author{
Junita*, Ernawati \\ Jurusan Keperawatan Poltekkes Kemenkes Jambi \\ *Alamat Korespondensi: ita_bynita@yahoo.co.id
}

\begin{abstract}
ABSTRAK
Latar Belakang: Stroke adalah keadaan yang timbul karena terjadi gangguan peredaran darah diotak yang menyebabkan terjadinya kematian jaringan otak sehingga mengakibatkan seseorang menderita kelumpuhan dan kematian. Di Indonesia, stroke merupakan penyakit nomor tiga yang mematikan setelah jantung dan kanker. Bahkan, menurut survei tahun 2004, stroke merupakan pembunuh no.1 di RS Pemerintah di seluruh penjuru Indonesia. Penelitian ini bertujuan untuk mengetahui hubungan antara rasio kadar kolesterol total terhadap HDL, rasio lingkar pinggang terhadap panggul dengan kejadian stroke di RSUD Raden Mattaher Jambi..

Metode: Penelitian ini menggunakan disain cross sectional, Populasi adalah pasien yang menderita stroke dan tidak stroke dirawat di ruang perawatan RSUD Raden Mattaher Jambi dan sampel berjumlah 99 responden. Pengumpulan data dilaksanakan pada tanggal 8 sampai dengan 26 Agustus 2016

Hasil: Hasil penelitian menunjukkan rata-rata kadar kolesterol total dan rata-rata HDL responden yang menderita stroke lebih rendah dari yang tidak stroke yaitu $233,33 \mathrm{mg} / \mathrm{dl}$ dan $45,45 \mathrm{mg} / \mathrm{dL}$. Sebanyak 26,3\% responden mempunyai rasio kolesterol HDL berisiko. Ada hubungan antara rasio kolesterol total terhadap HDL dengan kejadian penyakit Stroke ( $p$ value 0,001). Sebanyak 60,6\% responden mempunyai rasio lingkar pinggang dan lingkar panggul berisiko. Ada hubungan antara rasio lingkar pinggang panggul dengan kejadian penyakit stroke ( $p$ value 0,05) di RSUD RadenMattaher tahun 2016.

Kesimpulan: Rasio kolesterol total-HDL dan Rasio lingkar pinggang-panggul memiliki hubungan signifikan terhadap terjadinya stroke.
\end{abstract}

Kata kunci: kolesterol; HDL; lingkar pinggang; lingkar panggul; stroke

\section{THE RELATIONSHIP BETWEEN TOTAL CHOLESTEROL-HDL RATIO AND HIP-WAIST RATIO WITH STROKE AT RSUD RADEN MATTAHER 2016}

\begin{abstract}
Background: Stroke is a condition that occurs when the blood supply to part of the brain is interrupted, which can make brain damage and can lead to body paralysis or even death. Stroke is the third most common killer disease after heart disease and cancer in Indonesia. According to 2004 survey, stroke was the first common killer disease in Government hospital around Indonesia. The aim of this resesearch was to determinethe relationship between total cholesterol ration with HDL and between hip-waist ration with stroke at RSUD Raden Mattaher in 2016

Methods: This was a cross sectional research in a population of pastients with and without stroke at RSUD Raden Mattaher Jambi. The sample in this research were 99 respondents. Data were collected between 8-26 August 2016. Results: Result showed that the mean total cholesterol level and mean HDL level of respondents who had stroke was lower $(233,33 \mathrm{mg} / \mathrm{dl}$ and $45,45 \mathrm{mg} / \mathrm{dL}$ respectively) than the respondents who didn't have stroke. About 26,3\% of respondents had a risked total cholesterol-HDL ratio. There was a significant relationship between total cholesterol and HDL ratio with stroke ( $p$ value 0,001). About 60,6\% respondents were at risked hip-waist ratio level. There was a significant relationship between hip-waist ratio with ( $p$ value 0,05) at RSUD RadenMattaher in 2016.

Conclusion: There a significant relationship between tottal cholesterol-HDL ratio and hip-waist ratio with stroe iat RSUD Raden Mattaher Jambi in 2016.
\end{abstract}

Keywords: cholesterol; HD; waist measurement; hip measurement; stroke 


\section{PENDAHULUAN}

Stroke adalah keadaan yang timbul karena terjadi gangguan peredaran darah diotak yang menyebabkan terjadinya kematian jaringan otak sehingga mengakibatkan seseorang menderita kelumpuhan dan kematian ${ }^{1}$. Menurut Yayasan Stroke Indonesia (Yastroki), terdapat kecenderungan meningkatnya jumlah penyandang stroke di Indonesia dalam dasawarsa terakhir. Kecenderungannya menyerang generasi muda yang masih produktif. Hal ini akan berdampak terhadap menurunnya tingkat produktifitas serta dapat mengakibatkan terganggunya sosial ekonomi keluarga.

Di Indonesia, stroke merupakan penyakit nomor tiga yang mematikan setelah jantung dan kanker. Bahkan, menurut survei tahun 2004, stroke merupakan pembunuh no.1 di RS Pemerintah di seluruh penjuru Indonesia. Diperkirakan ada 500.000 penduduk yang terkena stroke. Dari jumlah tersebut, sepertiganya bisa pulih kembali, sepertiga lainnya mengalami gangguan fungsional ringan sampai sedang dan sepertiga sisanya mengalami gangguan fungsional berat yang mengharuskan penderita terus menerus di kasur. ${ }^{2}$

Widjaja dalam penelitiannya di instalasi rawat inap RSUP Sanglan Denpasar mengemukakan bahwa pada penderita stroke iskemik paling banyak terjadi pada rentang usia $>55-56$ tahun. ${ }^{3}$ Penyakit stroke iskemik dengan hipertensi sebagian besar terjadi pada laki-laki yaitu $61,11 \%$. Sebanyak $77,78 \%$ pasien tercatat mengalami riwayat hipertensi sebelumnya dan $55,56 \%$ pasien mengalami komplikasi dengan hipertensi, diabetes Melitus, dislipidemia maupun kombinasi ketiganya. Hasil Riset Kesehatan Dasar (Riskesdas) $2013^{4}$ diketahui penyakit stroke merupakan urutan prevalensi nomor empat terbanyak di Indonesia setelah penyakit hipertensi, rematik dan hepatitis B. Terjadi peningkatan stroke 8,3 per1000 pada tahun 2007 menjadi 12,1 per1000 pada tahun 2013.

Peningkatan kadar kolesterol seiring dengan bertambahnya risiko penyakit jantung koroner, namun hubungan antara tingkat kolesterol dan risiko stroke masih belum jelas. Stroke dapat disebabkan karena hipertensi. Obesitas merupakan faktor risiko yang penting untuk terjadinya hipertensi.
Overweight dan obesitas dapat menyebabkan kelainan metabolisme yang dapat mempengaruhi tekanan darah, kolesterol, trigliserid, dan resistensi hormon insulin ${ }^{5}$.

Tekanan darah meningkatkan seiring dengan bertambahnya usia. Hasil penelitian Budiarti $(2015)^{6}$ menunjukkan ada hubungan yang signifikan lingkar pinggang dan kolesterol dengan tekanan darah. Lingkar pinggang dan kadar kolesterol toral merupakan faktor yang dapat mempengaruhi tekanan darah. Pengukuran rasio lingkar pinggang dan pinggul lebih sensitif dalam menilaii distribusi lemak dalam tubuh terutama yang berada di dinding abdomen. Rasio lingkar pinggang dan pinggul dihitung dengan membagi ukuran lingkar pinggang dengan lingkar pinggul. Ukuran lingkar pinggang, menggambarkan tingginya deposit lemak berbahaya dalam tubuh sementara lingkar pinggul merupakan faktor protektif terhadap kejadian penyakit kardiovaskuler. Faktor risiko kardiovaskuler akan muncul apabila rasio lingkar pinggang dan pinggul dengan nilai lebih atau sama dengan 0,85 pada perempuan dan 0,90 pada laki-laki ${ }^{7}$.

Rumah Sakit Umum Daerah Raden Mattaher Jambi merupakan rumah sakit pusat rujukan di Propinsi Jambi yang melakukan perawatan pada penderita stroke. Data dari ruang Neurologi RSUD Raden Mattaher Jambi, bahwa kunjungan rawat inap penderita stroke cenderung mengalami peningkatan. Berdasarkan data RSUD Raden Mattaher Jambi jumlah pasien yang dirawat dengan penyakit stroke setiap tahun mengalami peningkatan. Pada tahun 2012 jumlah pasien stroke sebanyak 289 kasus, meningkat pada tahun 2013 sebanyak 463 kasus dan meningkat tahun 2014 menjadi 502 kasus $^{8}$.

Berdasarkan uraian diatas maka rumusan masalah penelitian ini adalah bagaimanakah hubungan antara rasio kadar kolesterol total terhadap HDL serta rasio lingkar pinggang terhadap panggul dan jenis kelamin dengan penderita stroke di RSUD Raden Mattaher Jambi tahun 2016?

\section{METODE}

Penelitian ini adalah penelitian observasional analitik dengan disain cross sectional studi dengan menggunakan kelompok pembanding. 
Populasi dalam penelitian ini adalah semua pasien yang menderita stroke dan bukan stroke dirawat di ruang perawatan RSUD Raden Mattaher Jambi.

Teknik pengambilan sampel dilakukan secara non random. Caranya adalah dengan menemukan pasien stroke dan non stroke di ruang perawatan RSUD Raden Mattaher Jambi pada saat periode penelitian. Karena pasien stroke hemoragic angka kejadiannya kecil sehingga peneliti menggunakan kelompok pembanding yaitu pasien yang tidak menderita stroke namun berisiko untuk mengalami stroke.

Besar sampel penderita stroke Non Haemoragic sebesar 33 orang. Dikarenakan angka kejadian kecil, maka peneliti membuat kelompok pembanding dengan jumlah sampel dua kali lipat dari sampel pasen stroke yaitu 66 orang. Sehingga total jumlah sampel berjumalh 99 responden. Kriteria inklusi adalah responden dengan umur diatas 40 tahun dan eksklusi pasien yang mengalami stroke haemorogic.

Pengumpulan data penelitian di RSUD Raden Mattaher dilaksanakan dari tanggal 08 sampai dengan 26 Agustus 2016. Penelitian ini dilaksanakan di 5 ruang perawatan yaitu ruang penyakit dalam, ruang neurologi, ruang perawatan kelas 1, ruang perawatan kelas 2, ruang VIP Pinang Masak dan ruang VIP Mayang Mengurai.

Pada tahap persiapan pengumpulan data dilakukan persiapan instrumen penelitian dan administarasi. Pada tahan pengumpulan data dengan memilih responden sesuai kriteria inklusi dan eksklusi, memberikan informasi penelitian kepada responden dengan jelas, meminta persetujuan pasien untuk menjadi responden serta melakukan wawancara dan pengukuran lingkar pinggang dan panggul pada responden terpilih.

Variabel dependen stroke didapatkan dengan melakukan telaah rekam medik dengan hasil ukur stroke dan non stroke. Variabel Kolesterol Total diukur dengan cara telaah rekam medik kadar kolesterol total responden yang sudah tercatat dalam rekam medik, variabel HDL didapat dengan cara telaah rekam medik, Rasio Kolesterol dan HDL adalah suatu keadaan pasien dimana kadar kolesterol total pasien dibandingkan dengan kadar HDL dengan hasil ukur Berisiko jika hasilnya pada wanita $\leq 4,5$ dan pria $\leq 4,0$. Lingkar pinggang merupakan hasil pengukuran panjang lingkar pinggang yang diukur antara crista iliaka dan kosta XII pada linkar terkecil.
Lingkar Panggul adalah hasil pengukuran panjang lingkar panggul yang diukur pada lingkar maksimal dari pantat dan pada bagian atas simpisis ossis pubis dan rasio lingkar pinggang lingkar panggul adalah perbandingan antara hasil pengukuran lingkar pinggang dan lingkar panggul dengan hasil ukur Berisiko jika hasilnya pada wanita $>0,80$ dan pria $>0,90$.

Analisis data secara univariat dalam bentuk penyajian tabel distribusi frekuensi dan tekstular. Sedangkan analisis bivariat menggunakan uji chi square

\section{HASIL DAN PEMBAHASAN}

Data kadar kolesterol total didapat dengan cara melihat hasil pemeriksaan kadar kolesterol total yang telah dilakukan di bagian laboratorium RSUD Raden Mattaher Jambi. Dalam analisis ini akan dilihat rata-rata kadar kolesterol total responden. Untuk lebih jelas dapat dilihat seperti tabel dibawah ini:

Tabel 1. Distribusi Rata-Rata Kadar Kolesterol dan HDL Pada Penderita Stroke di RSUD Raden Mattaher Jambi Tahun 2016

\begin{tabular}{lcccccccc}
\hline \multicolumn{4}{c}{ Stroke } & \multicolumn{4}{c}{ Non Stroke } \\
\hline & Mean & Median & SD & $\begin{array}{c}\text { Min- } \\
\text { Max }\end{array}$ & Mean & Median & SD & Min-Max \\
\hline $\begin{array}{l}\text { Kolesterol } \\
\text { Tot }\end{array}$ & 233,33 & 237,00 & 41,965 & $135-339$ & 251,46 & 236,00 & 64,758 & $130-510$ \\
\hline HDL & 45,45 & 42,00 & 18,338 & $15-90$ & 46,11 & 41 & 13,548 & $21-78$ \\
\hline $\begin{array}{l}\text { Lingkar } \\
\text { Pinggang }\end{array}$ & 80,04 & 80,20 & 8,444 & $58-91$ & 78,58 & 78,58 & 4,923 & $70-91$ \\
\hline $\begin{array}{l}\text { Lingkar } \\
\text { panggul }\end{array}$ & 80,88 & 84,10 & 15,985 & $60-95$ & 83,95 & 84,5 & 4,590 & $74-92$ \\
\hline
\end{tabular}

Hasil penelitian menunjukkan rata-rata kadar kolesterol total responden yang menderita stroke adalah $233,33 \mathrm{mg} / \mathrm{dl}$, sedangkan rata-rata kadar kolesterol total responden yang tidak menderita stroke adalah 251,46. Jika dilihat dari data tersebut ternyata rata-rata kadar kolesterol total penderita yang tidak stroke lebih tinggi dibandingkan rata-rata kadar kolesterol penderita yang mengalami stroke.

Menurut WHO dalam Muttaqin, stroke adalah adanya tanda-tanda klinik yang berkembang cepat akibat gangguan fungsi otak fokal (global) dengan gejala-gejala yang berlangsung selama 24 jam atau lebih yang menyebabkan kematian tanpa adanya penyebab lain yang jelas selain vaskuler. ${ }^{9}$ Menurut Setiopranoto, faktor risiko stroke salah satunya adalah dislipidemia. ${ }^{10}$ Dislipidemia merupakan suatu keadaan meningkatnya kadar kolesterol dalam darah. 
Kolesterol LDL disebut sebagai kolesterol jahat, yang membawa kolesterol dari hati ke dalam sel. Jumlah kolesterol LDL yang tinggi akan menyebabkan penimbunan kolesterol di dalam sel. Hal ini akan memacu munculnya proses atherosklerosis (pengerasan dinding pembuluh darah arteri). Proses atherosclerosis akan menimbulkan komplikasi pada organ target (jantung, otak, dan ginjal). Proses tersebut pada otak akan meningkatkan risiko terkena stroke.

Namun hasil penelitian ini menunjkkan rata-rata kadar kolesterol penderita yang tidak stroke lebih tinggi dibandingkan penderita yang mengalami stroke.

Kadar kolesterol total diatas $200 \mathrm{mg} / \mathrm{dL}$ merupakan faktor risiko terjadinya stroke. Pada responden yang bukan stroke hampir sebagian besar mengalami penyakit hipertensi. Menurut Kowalski. E.Robert $(2010)^{11}$ seseorang disebut mengalami hipertensi apabila tekanan darahnya lebih dari 140/90 $\mathrm{mmHg}$ atau lebih dari 135/85 pada individu yang mengalami gagal jantung, insufisiensi ginjal, atau diabetes mellitus. Hipertensi meningkatkan risiko stroke 2-4 kali lipat tanpa tergantung pada faktor risiko lainnya.

Faktor risiko tingginya kolesterol total di dalam darah dapat menyebabkan terjadinya stroke, sehingga dapat disarankan kepada pihak RS agar memperhatikan kondisi pasien yang mengalami hipertensi, karena hipertensi yang dialami oleh pasien sangat berisiko sekali untuk mengalami stroke. Perlunya perawatan yang komprehensif dan menjaga pola makan yang baik pada penderita hipertensi agar penderita tidak mengalami komplikasi stroke.

Data kadar HDL didapat dengan cara melihat hasil pemeriksaan kadar HDL yang telah dilakukan di bagian laboratorium RSUD Raden Mattaher Jambi. Dalam analisis ini akan dilihat rata-rata kadar HDL responden.

Hasil penelitian menujukkan rata-rata HDL responden yang menderita stroke adalah 45,45 mg/dl dan rata-rata kadar HDL responden yang tidak menderita stroke adalah 46,11. Jika dilihat dari nilai HDL ternyata rata-rata HDL penderita yang tidak mengalami stroke sedikit lebih tinggi dibandingkan penderita yang mengalami stroke. HDL (High Density Lipoprotein) sering disebut kolesterol baik. Semakin tinggi tingkat HDL, maka akan semakin baik untuk kesehatan, karena HDL melindungi dari penyakit jantung. Tingkat HDL minimal 60 $\mathrm{mg} / \mathrm{dL}$ atau lebih dapat membantu mengurangi risiko penyakit jantung, dan sebaliknya tingkat HDL kurang dari $40 \mathrm{mg} / \mathrm{dL}$ justru menaikkan risiko penyakit jantung.
Dari hasil penelitian terlihat bahwa ratarata kadar HDL antara penderita yang mengalami stroke dan tidak stroke semuanya di bawah 60 $\mathrm{mg} / \mathrm{dL}$. Jika dilihat dari nilai tersebut bahwa responden yang tidak stroke mempunyai ratarata nilai stroke yang berisiko. Nilai kadar HDL yang kecil dari $60 \mathrm{mg} / \mathrm{dL}$ dapat merisiko untuk mengalami stroke.

Data tentang ukuran lingkar pinggang didapat dengan cara melakukan pengukuran lingkar pinggang pada responden oleh peneliti dengan posisi pasien berdiri. Dalam analisis ini akan dilihat rata-rata besaran lingkar pinggang responden. Hasil penelitian menunjukkan bahwa rata-rata lingkar pinggang responden yang menderita stroke adalah $80,04 \mathrm{~cm}$, sedangkan rata-rata lingkar pinggang responden yang tidak menderita stroke adalah $78,58 \mathrm{~cm}$. Lingkar pinggang adalah indikator untuk menentukan obesitas abdominal yang diperoleh melalui hasil pengukuran panjang lingkar yang diukur di antara crista illiaca dan costa XII pada lingkar terkecil, diukur dengan pita meteran non elastis (ketelitian $1 \mathrm{~mm}$ ). Bertambahnya ukuran lingkar pinggang berhubungan dengan peningkatan prevalensi hipertensi ${ }^{11}$.

Lemak di perut adalah lemak paling berbahaya. Lemak yang berada di perut bagian dalam ini bakal mengeluarkan asam lemak bebas dan puluhan hormon yang bakal menimbulkan beragam masalah seperti menaiknya tekanan darah, terjadinya resistensi insulin, dan masih banyak masalah lain. yang cukup berrat seperti munculnya penyakit jantung dan stroke.

Beberapa Penelitian terdahulu menjelaskan bahwa ukuran lingkar pinggang yang besar berhubungan dengan tingginya tekanan darah, ukuran lingkar pinggang yang besar berhubungan dengan peningkatan faktor risiko terhadap penyakit kardiovaskular karena lingkar pinggang dapat menggambarkan akumulasi dari lemak intraabdominal atau lemak visceral. Pada penelitian Pradana $(2010)^{12}$ didapatkan bahwa ada hubungan antara rasio lingkar pinggang lingkar panggung dengan tekanan darah diastolik pada sunyek perempuan dan laki-laki, namun tidak ada hubungan bermakna dengan tekanan darah sistole.

Lingkar pinggang merupakan faktor risiko penyakit kardiovaskular yang paling menentukan jika dibandingkan dengan pengukuran IMT.

Pengukuran lingkar panggul dilakukan dengan cara melakukan pengukuran antara crista iliaka dan kosta XII pada linkar terkecil dengan menggunakan pita centimeter non elastik. 
Hasil penelitian menunjukkan bahwa rata-rata lingkar panggul responden yang mengalami stroke $80,88 \mathrm{~cm}$ dan rata-rata lingkar panggul responden yang non stroke adalah 83,95 . Lingkar panggul adalah indikator untuk menentukan obesitas abdominal yang diperoleh melalui hasil pengukuran panjang lingkar yang diukur pada lingkar maksimal dari pantat dan pada bagian atas simpysis ossis pubis.Lingkar panggul yang besar (tanpa menilai IMT dan lingkar pinggang) memiliki risiko diabetes melitus dan penyakit kardiovaskular yang lebih rendah Pengukuran lingkar panggul dilaksanakan dengan posisi berdiri

Rasio kadar kolesterol terhadap HDL didapat dengan cara membagi niai kolesterol total dengan HDL. Hasilnya dikatakan berisiko jika hasil pembagian pada wanita $\leq 4,5$ dan pria $\leq 4,0$. Dari analisis dapat dilihat pada tabel 2 .

Tabel 2. Distribusi Responden Berdasarkan Rasio Kolesterol terhadap HDL Pada Pasien Stroke di RSUD Raden Mattaher Jambi Tahun 2016

\begin{tabular}{lcc}
\hline $\begin{array}{c}\text { Rasio Kolesterol } \\
\text { terhadap HDL }\end{array}$ & n & \% \\
\hline Berisiko & 26 & 26,3 \\
\hline Tidak Berisiko & 73 & 73,7 \\
\hline Jumlah & 99 & 100 \\
\hline
\end{tabular}

Hasil penelitian menunjukkan 26,3\% responden dengan rasio kolesterol HDL berisiko. Resiko terjadinya stroke akan meningkat bila terjadi peningkatan kadar kolesterol total yang diikuti dengan penurunan kadar HDL. Pada situasi ini rasio antara kadar kolesterol total terhadap HDL akan naik sehingga dapat memicu terbentuknya aterosklerosis. Rasio kolesterol total terhadap HDL merupakan prediktor kuat terhadap risiko stroke.

Risiko stroke dihitung dengan membagi kolesterol total dengan HDL Rekomendasi rasio kolesterol total terhadap HDL oleh National Cholesterol Education Program (NCEP) yaitu lebih rendah atau sama dengan 4,5 untuk pria atau lebih rendah atau sama dengan 4,0 pada wanita $^{13}$. Penelitian di Indonesia mengenai rasio ideal antara kolesterol total terhadap HDL diperoleh hasil bahwa risiko tinggi bila $>4$ dan normal bila $\leq 4$. Rasio tersebut bersifat relatif tiapi individu ${ }^{14}$. Meningkatnya kadar kolesterol dalam darah terutama LDL, akan menyebabkan terjadinya aterosklerosis. Dari hasil penelitian jika dilihat dari jenis kelamin laki-laki sebanyak $23,4 \%$ responden dengan rasio kolesterol terhadap HDL yang berisiko, sedangkan responden perempuan, sebanyak $31,4 \%$ responden dengan rasio kolesterol terhadap HDL berisiko.

Dari data tersebut dapat diketahui bahwa lebih banyak responden perempuan yang mengalami stroke dengan rasio kolesterol terhadap HDL berisiko.

Rasio lingkar pinggang terhadap lingkar panggul didapat dengan cara membagi hasil pengukuran lingkar pinggang dengan lingkar panggul. Hasilnya dikatakan berisiko jika pada wanita $>0,80$ dan pria $>0,90$. Dari analisis dapat dilihat pada tabel 3 .

Tabel 3. Distribusi Responden Berdasarkan Rasio Lingkar Pinggang Panggul Pada Pasien Stroke di RSUD Raden Mattaher Jambi Tahun 2016

\begin{tabular}{lcc}
\multicolumn{1}{c}{$\begin{array}{c}\text { Rasio Lingkar Pinggang } \\
\text { Panggul }\end{array}$} & n & \% \\
\hline Berisiko & 60 & 60,6 \\
\hline Tidak Berisiko & 39 & 39,4 \\
\hline Jumlah & 99 & 100 \\
\hline
\end{tabular}

Hasil penelitian menunjukkan sebagian besar $(60,6 \%)$ responden dikategorikan rasio lingkar pinggang dan lingkar panggul berisiko. Rasio lingkar pinggang panggul (RLPP) adalah indikator untuk menentukan obesitas abdominal yang diperoleh dengan cara menghitung perbandingan antara lingkar pinggang $(\mathrm{cm})$ dan lingkar panggul $(\mathrm{cm})$. RLPP dapat dipakai untuk mendeteksi kelebihan lemak tubuh pada seseorang dan akurat untuk mendeteksi risiko penyebab PJK, beberapa jenis kanker, hiperkolesterolemia, hipertensi.

World Health Organization ${ }^{5}$ secara garis besar menentukan kriteria obesitas berdasarkan rasio lingkar pinggang panggul jika rasio lingkar pinggang panggul pria $>0,90$ dan pada wanita $>$ 0,80 . Jika ditinjau dari jenis kelamin, sebanyak $57,8 \%$ responden dengan rasio lingkar pinggang terhadap panggul yang berisiko, sedangkan dari 35 responden perempuan, sebanyak $23(65,7 \%)$ responden dengan rasio lingkar pinggang terhadap panggul yang berisiko.

Rasio lingkar pinggang panggul (RLPP) dapat dipakai untuk mendeteksi kelebihan lemak tubuh pada seseorang dan akurat untuk mendeteksi risiko penyebab PJK, beberapa jenis kanker, hiperkolesterolemia, hipertensi. Beberapa hasil penelitian menunjukkan bahwa RLPP akan meningkat dengan bertambahnya umur. Selain itu RLPP berkaitan dengan tingkat social ekonomi dan aktifitas fisik, dan pada pria berkaitan erat dengan konsumsi alkohol. Penelitian yang dilakukan di kodya Bogor menemukan bahwa ada kencenderungan peningkatan tekanan darah pada kelompok RLPP 
tinggi dan ditemukan lebih banyak penderita hipertensi. Selain itu RLPP $\geq 0.85$ kadar trigliserida darah melebihi batas normal demikian juga kadar kolesterol darah semakin meningkat, dengan demikian RLPP dapat dipakai sebagai indikator yang sederhana untuk mengetahui risiko penyakit degeneratif

Analisis hubungan antara rasio kadar kolesterol total terhadap HDL dengan kejadian stroke dapat dilihat pada tabel4.

Tabel 4. Distribusi Responden Berdasarkan Rasio Kadar Kolesterol Total Terhadap HDL Dan Kejadian Stroke di RSUD Raden Mattaher Jambi tahun 2016

\begin{tabular}{lccccccc}
\hline $\begin{array}{l}\text { Rasio } \\
\text { Kolesterol }\end{array}$ & \multicolumn{3}{c}{ Kejadian Stroke } & Total & P value \\
\cline { 2 - 5 } $\begin{array}{l}\text { Total } \\
\text { terhadap }\end{array}$ & Ya & \multicolumn{2}{c}{ Tidak } & & & \\
\cline { 2 - 6 } HDL & $\mathbf{n}$ & $\mathbf{\%}$ & $\mathbf{n}$ & $\mathbf{\%}$ & $\mathbf{n}$ & $\mathbf{\%}$ & \\
\hline Berisiko & 16 & 61,5 & 10 & 38,5 & 26 & 100 & 0,001 \\
\hline Tidak Berisiko & 17 & 23,3 & 56 & 76,7 & 73 & 100 & \\
\hline Total & 33 & 33,3 & 66 & 66,7 & 99 & 100 & \\
\hline
\end{tabular}

Hasil penelitian menunjukkan bahwa ada hubungan antara rasio kolesterol total terhadap HDL dengan kejadian penyakit Stroke. Lebih lanjut dapat dijelaskan bahwa risiko stroke akan terjadi 5 kali pada penderita yang mempunyai rasio kolesterol total terhadap HDL pada wanita $\leq 4,5$ dan pria $\leq 4,0$. Dari data menunjukkan $61,5 \%$ responden yang memiliki rasio kolesterol terhadap HDL dengan nilai berisiko menderita penyakit stroke. Sedangkan dari responden dengan kadar rasio kolesterol terhadap HDL dengan nilai tidak berisiko, sebanyak 23,3\% responden menderita penyakit stroke.

Resiko terjadinya stroke akan meningkat bila terjadi peningkatan kadar kolesterol total yang diikuti dengan penurunan kadar HDL. Pada situasi ini rasio antara kadar kolesterol total terhadap HDL akan naik sehingga dapat memicu terbentuknya aterosklerosis. Rasio kolesterol toal terhadap HDL merupakan prediktor kuat terhadap risiko stroke ${ }^{15}$.

Rasio kolesterol total dengan kolesterol HDL merupakan prediktor kuat dari risiko $\mathrm{PJK}^{15}$. Rasio kolesterol total terhadap HDL berkorelasi positif dengan risiko PJK, penting diperhatikan karena nilainya lebih bermakna terhadap kemungkinan risiko terjadinya PJK. Rasio kolesterol total dengan kolesterol HDL memberikan informasi lebih lanjut tentang risiko penyakit jantung dari pada tingkat total olesterol saja.

Sementara itu HDL dianggap kolesterol baik antiaterogenik, terlibat dalam transportasi balik dari lipid. Studi epidemiologis telah menemukan hubungan yang berbanding terbalik antara kadar HDL dan risiko PJK. Bila dikelompokkan menurut tingkat HDL, subjek dengan kadar HDL lebih dari $60 \mathrm{mg} / \mathrm{dL}$ memiliki risiko PJK lebih rendah dibandingkan mereka yang memiliki HDL 40-60 mg/dL, tingkat ini masih memiliki risiko yang lebih rendah daripada mereka yang memiliki HDL kurang dari $40 \mathrm{mg} / \mathrm{dL}$. Tidak ada batas optimal untuk efek menguntungkan dari HDL pada risiko PJK yang telah diidentifikasi. Kadar HDL plasma diatas 75 $\mathrm{mg} / \mathrm{dL}$ berefek perlindungan dari aterosklerosis dan kebebasan relatif dari PJK. Peningkatan 1 $\mathrm{mg} / \mathrm{dL}$ dari HDL menurunkan risiko PJK sebesar $2 \%$ pada pria dan $3 \%$ pada wanita ${ }^{16}$

HDL memiliki banyak efek, termasuk transportasi kolesterol balik, antioksidan, antiinflamasi, dan sifat antitrombotik yang diyakini sebagai atheroprotektif. Efek anti-inflamasi HDL termasuk membatasi ekspresi molekul adhesi leukosit pada permukaan sel endotel, mengurangi kemotaksis leukosit, dan penurunan ekspresi dari sejumlah sitokin, termasuk interleukin 1 dan 6 serta Tumor Necrosis Factor$\alpha(\mathrm{TNF}-\alpha)$. HDL cenderung berkontribusi sebagai penaksiran "faktor risiko negatif" pada penyakit jantung koroner.

Hasil penelitian ini sejalan dengan penelitian yang dilakukan Firdiansyah $(2014)^{16}$ bahwa adanya hubungan antara antara rasio kadar kolesterol total terhadap HDL pada pasien PJK. Menurut Davey Patrick ${ }^{17}$ bahwa hubungan antara rasio kadar kolesterol total terhadap HDL berhubungan signifikan penyakit jantung koroner.

Kolesterol berasal dari makanan, makanan yang mengandung lemak jenuh dapat meningkatkan kolesterol dalam darah, untuk itu perlu mengurangi konsumsi makanan yang berasal dari lemak jenuh. Dengan pengaturan diet dan olahraga yang sesuai dengan kondisi pasien dapat mengurangi risiko kolesterol dalam darah dan otomatis bisa mengurangi faktor risiko terjadinya stroke

Analisis hubungan antara rasio lingkar pinggang panggul dengan kejadian stroke dapat dilihat pada tabel 5 .

Tabel 5. Distribusi Responden Berdasarkan Rasio Lingkar Pinggang Panggul Dan Kejadian Stroke di RSUD Raden Mattaher Jambi tahun 2016

\begin{tabular}{|c|c|c|c|c|c|c|c|}
\hline \multirow{3}{*}{$\begin{array}{l}\text { Rasio } \\
\text { Lingkar } \\
\text { Pinggang } \\
\text { Panggul }\end{array}$} & \multicolumn{4}{|c|}{ Kejadian Stroke } & \multirow{2}{*}{\multicolumn{2}{|c|}{ Total }} & \multirow[t]{3}{*}{ P value } \\
\hline & \multicolumn{2}{|l|}{$\overline{Y a}$} & \multicolumn{2}{|c|}{ Tidak } & & & \\
\hline & $\mathbf{n}$ & $\%$ & $\mathbf{n}$ & $\%$ & $\mathbf{n}$ & $\%$ & \\
\hline Berisiko & 25 & 41,7 & 35 & 58,3 & 60 & 100 & 0,05 \\
\hline Tidak Berisiko & 8 & 20,5 & 31 & 79,5 & 39 & 100 & \\
\hline Total & 33 & 33,3 & 66 & 66,7 & 99 & 100 & \\
\hline
\end{tabular}


Hasil penelitian menunjukkan ada hubungan antara rasio lingkar pinggang panggul dengan kejadian penyakit stroke, artinya bahwa rasio lingkar pinggang dan panggul pada wanita $>0,80$ dan pria $>0,90$ mempunyai risiko tinggi untuk mengalami stroke. Hasil ini juga diperkuat dengan data bahruwa rasio lingkar pinggang dan panggul pada wanita $>0,80$ dan pria $>0,90$ akan berisiko hampir 3 kali untuk mengalami terkena stroke. Dari data didapatkan responden yang memiliki rasio lingkar pinggang panggul berisiko berisiko lebih banyak menderita penyakit stroke dibandingkan dengan responden yang memiliki rasio lingkar pinggang panggul yang tidak berisiko.

Hasil penelitian Sunarti dan Maryani $(2012)^{18}$ menunjukkan ada hubungan antara rasio lingkar pinggang dan panggul dengan kejadian kejadian PJK pada pasien di RSUD Kabupaten Sukoharjo.

Pada wanita usia 70-80 tahun setiap peningkatan 0,1 inci pada rasio lingkar pinggang panggul dapat menjadi faktor predisposisi peningkatan kematian sebesar 28\%. World Health Organization $(2013)^{5}$ secara garis besar menentukan kriteria obesitas berdasarkan rasio lingkar pinggang panggul jika rasio lingkar pinggang panggul pria $>0,90$ dan pada wanita $>$ 0,80 . Untuk itu diharapkan kepada masyarakat khususnya lansia agar menerapkan pola makan yang baik untuk menghindari terjadinya penumpukan lemak di bagian perut. Disamping itu olahraga ringan bisa mengurangi risiko kelebihan berat badan.

\section{KESIMPULAN}

Rata-rata kadar kolesterol total responden yang menderita stroke adalah $233,33 \mathrm{mg} / \mathrm{dl}$ dan lebih rendah dibandingkan yang tidak menderita stroke yaitu 251,46 mg/dl. Nilai rata-rata HDL responden yang menderita stroke juga sedikit lebih rendah yaitu 45,45 $\mathrm{mg} / \mathrm{dl}$ dibandingkan responden yang tidak menderita stroke yaitu $46,11 \mathrm{mg} / \mathrm{dl}$. Sebanyak 26,3\% responden memiliki rasio kolesterol-HDL berisiko yaitu nilai pembagian kadar olesterol total dibagi kadar HDL pada wanita $\leq 4,5$ dan pria $\leq 4,0$. Hasil penelitian menunjukkan ada hubungan antara rasio kolesterol total terhadap HDL dengan kejadian penyakit Stroke ( $p$ value 0,001 ).

Sebagian besar $(60,6 \%)$ responden dikategorikan rasio lingkar pinggang dan lingkar panggul berisiko yaitu jika hasil rasio pengukuran lingkar pinggang dengan lingkar panggul pada wanita $>0,80$ dan pria $>0,90$. Ada hubungan antara rasio lingkar pinggang panggul dengan kejadian penyakit stroke ( $p$ value 0,05$)$.

\section{DAFTAR PUSTAKA}

1. Batticaca. Asuhan Keperawatan Klien dengan Gangguan Sistem Persyarafan. Penerbit Salemba Medika Jakarta. 2008.

2. Suci, Wice Purwani, Bayhakki. Hubungan Kemampuan Keluarga Merawat Klien Pasca Stroke Dengan Kekambuhan Klien Pasca Stroke. Jurnal Ners Indonesia. 2011; 2(1): 72-78

3. Widjaja. Efektifitas Penggunaan Captropil Dalam Penanganan Hipertensi pada Pasien Stroke Iskemik di Instalasi Rawat Inap RSUP Sanglah Denpasar, Jurnal. 2004.

4. Badan Penelitian dan Pengembangan Kesehatan, Departemen Kesehatan Republik Indonesia Riset Kesehatan Dasar (RISKESDAS) 2013. Jakarta

5. WHO. Cardiovascular Diseases. World Health Organization. Geneva. 2013.

6. Budiarti, T. Hubungan Lingkar Pinggang dan Kadar Kolesterol Total dengan Tekanan Darah pada Wanita Usia 46-55 tahun di Desa Singocandi Kecamatan Kota Kabupaten Kudus. Skripsi. Program Studi Ilmu Gizi Stikes Ngudi Waluyo. 2015.

7. Supariasa Nyoman Dewa I, dkk. Penilaian Status Gizi (Edisi Revisi). Jakart. Penerbit Buku Kedokteran EGC. 2013.

8. RSUD Raden Mattaher. Profil Rumah Sakit Umum Daerah Raden Mattaher Jambi. 2015.

9. Muttaqin. Buku Ajar Asuhan Keperawatan Dengan Gangguan Sistem Persyarafan. Penerbit Salemba Medika. Jakarta. 2008.

10. Setyopranoto. I. Stroke: Gejala dan Penatalaksanaan. CDK. 2011.

11. Kowalski. Robert E. Terapi Hipertensi: Program 8 Minggu Menurunkan Tekanan Darah Tinggi dan Mengurangi Risiko Serangan Jantung dan Stroke Secara Alami. Penerbit Qanita. Bandung. 2010.

12. Ernitasari Putu Diah., Djarwoto Bambang,. Siswati Tri. Pola Makan, Rasio Lingkar Pinggang Panggul (RLPP) dan Tekanan Darah di Puskesmas Mergangsan Yogyakarta. Jurnal Gizi Klinik Indonesia. 2006.

13. Pradana Nur Oviyanti Hubungan Antara Lingkar Pinggang Dan Rasio Lingkar Pinggang Panggul Dengan Tekanan Darah Pada Subyek Usia Dewasa. Fakultas Kedokteran Universitas Sebelas Maret, Surakarta. 2010.

14. Dalimartha, Setiawan. 36 Resep Tumbuhan Obat untuk Menurunkan Kolesterol. Penerbit Swadaya. Jakarta. 2008.

15. Soeharto I. Penyakit Jantung Koroner dan Serangan Jantung Jakartta : PT Gramedia Pustaka Utama. 2004: 73

16. Tisnadjaja. Jajat. Bebas Kolesterol dan Demam Berdarah dengan Angkak. Penerbit Swadaya Jakarta. 2006.

17. Firdiansyah, Muhammad HafidzHubungan Antara Total Rasio Kadar kolesterol Total 
Terhadap High-Density Lipoprotein (HDL) dengan Kejadian Penyakit Jantung Koroner di RSUD Dr. Moewardi. Skripsi thesis, Universitas Muhammadiyah Surakarta. 2014.

18. Davey Patrick. At a Glance Medicine. Penerbit Erlangga Jakarta. 2005.
19. Sunarti Sunarti dan Maryani, Elvira. Rasio Lingkar Pinggang dan Panggul dengan Penyakit Jantung Koroner di RSUD Kabupaten Sukoharjo. Journal article Buletin Penelitian Sistem Kesehatan. Januari 2013. Indobesia. 2012.

20. Fatimah, Detty N. Mencegah dan Mengatasi Stroke. Penerbit Kujang Press. Yogyakarta. 2009. 